\title{
History of the Quebec Forestry School.
}

By

Avila Bedard.

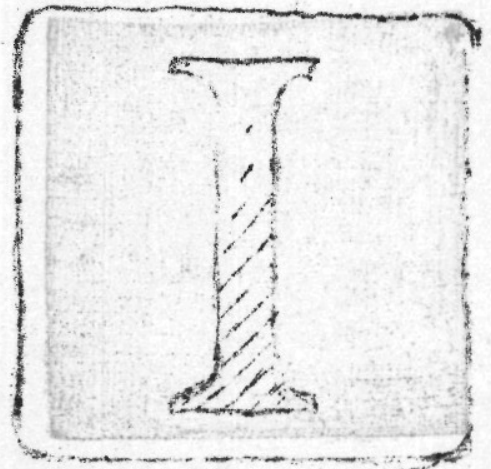

$t$ is now some 30 years, as you are all aware, since efforts vere first made in the interests of economy to give the forest resources of our country the important recognition they deserve. It hos been realized that these resources, of which the extent and wealth could not be exactly ascertained, were susceptible to depletion, not only through fire but also through abusive and unscientific cuttings. Some of the forest stands located close to the mills, in the more accessible sections of the river basins show, in the modification of their physiography, the conspicuous traces of disastrous influence which may have resulted from improper exploitations. Not only has their composition been modified, but also their yield. To quote but one example of the modifications which the aspect of some forest stands has undergone, let us remember that jn most cases where the forest has been intensively exploited to mest the requirements in white pine of industry and commerce, it has robuilt itself with a species which, corpared with the white pine, has long been considered as an inferior species. Within the white pine stands which formed the forest wealth of some of the most important river basins in Quebec, such as the Ottawa, the Gatineau, the Iievre, the Batiscan and the Jacques-Cartier, white pine has been roplaced by sprucs, a species which owes its reputation to the comparatively recent industry of pulp and paper. The modifications and the depletion of some forest stands under the influence of various factors are responsible, to a grect extent, for the forest enginesr coming into the limelight. On the other hand, the necessity fo find an outlet for hardwoods which would allow industry to derive benefit from a raw material which was discarded, and the utilization of which wo uld contribute to facilitate the application of silvicultural methods, is also responsible for the reputation which the forest engineer has achieved for himself.

Generally speaking, forest oporations have not been conducted, due to certain uncontroliable economic conditions, as to completely utilize the trees cut domn. As a result of these mudimentary methods, a considerable amount of wood material has been accumulating itself in the wake of the jobbers to hamper the regeneration of the forest or to constitute a fire hazard or a ready breeding place for insects or sungus disease. 
It is unquestionable that to control the forest exploitations a technical man is of absolute necessity. To nature alone must not be left the task of rebuilding the forest. Truly enough, it possesses all the means to achieve this purpose, but is it not obvious that nature proceeds in a reckless and fanciful way? Let us remember that nature does not particularize. She does not display her activities necessarily to meet the needs of man, and the requirements of industry and trade. To maintain in their useful state the different cultures which he has to resort to, in order to live and prosper, men cannot relax his efforts, or his activity. Therefore, are we not justified in saying that this action of man is necessary when it comes to bringing up the forest to yield the various products which are constantly required by industry and commerce? On the other hand, have we not the same rsasons to state that such an action will only be valuable if based on the most perfect as possible knowlecige of the laws of vegetation, the conditions of habitat to which the forest is confined and of the varied exigencies which the forest species show when they have to live in a comminty? Therefore, only a technicien can accomplish such a purpose, where a man who only can rely upon mere observation would fail.

It is agreed that silvicultural methods can only be resorted to where the iorest is easily accessible and where trees of different sizes can be taken out. On the other hand, in remote forests the methods of exploitation are always rudimentary and analogous to methods which were in use, many years ago, in the Canadian forests when rood industry and timber trade vere not as active and prosperous as they are to-day. The greater volume of raw raterial now required by industry and comerce, the ruggedness of the topographical units where are to be found the virgin timber resources, the necessity to resort to more elaborate and better means of transportation, all this has to a great extent modified the problems of timber transportation.

The conversion of raw material into useful commodities is also a problem which of late has undergone substantial and advantageous changes. Although the improvements brought about into the processes of manufacturing different wood products have been wonderful, yet they are not final. There is still room for improvement. It is the task of the technical man, of the man who has been thoroughly trained in scientific studies end laboratory researches, to achieve this progress.

In every section of the comtry the governiments and the puilic men heve realized the necessity to have some men of special training and instruction who could look alter the reconstitution and improvement of the forest and could also perfect the methods of exploitation and utilization of all wood products. They 
have also realized that in this country, the economical development was intimately related to the utilization of the stores of raw material and energy which nature has put to the service of men and have convinced themselves of the necessity of co-ordinating the human efforts in order to bring about as complete as possible a utilization of these stores of viealth.

This opinion is responsible for the creation in Canada, as it was in the United States, of many forest schools; of such schools as those of Toronto, Fredericton, quobec and Vancouver.

My intention is not to dwell at length upon the history of the Quebsc Forestry School, but it seems to me that in connection with it some facts should be put before you. In 1904, my friend, Mr. G.C. Fiche, the chiof of the Forest Service, wrote to the Provincial Secretary to urge upon him the necessity of establishing a school where technicol men could be trained to look after the tending of the Crom forests of vuebec. Mgr. Laflame, a very learned man, who has achieved a great reputetion, not only in Canada, but in other countries, wrote many articles at the same period, to educate public opinion in favour of such a creation. Sir Lomer Gouin, at the time Prime Minister of Quebec, in a. speech delivered in Montreal, in 1905, promised to create such a school and the same year sent Mir. Piche and myself to Yale to get a special training in forestry.

The Quebec Forest School was fpunded in 1910 by the Quebec government and affiliated to Laval University. At that time the course given coverod 2 years but it wes early ielt that the programme hed to be arranged and modified. This was achieved when the Surveying School and the Forest School were united in 1919.

The reason for combining the two schools lies in the fact that many subjocts (mathematics for instance) essential to the training of a Forest Engineer are also required for the training of a. Surveyor. On the other hand the Surveyor and the Forest Engineer are called upon to accomplish in certain sections of the country, a very much similar task. The fusion of the two schools has enabled us to dispose of a more substantial budget and to onlarge andimprove the progran of studies.

As it is now constituted the course covers four full years during which most of the subjects related to the practice of civil engineering, and all those connected with the application of forestry, are taught. The programme is arranged in such a manner that at the end of the third year the student gets the degree of Surveyor and at the end of the fourth year the degree of Forest Engineer.

To supplement and improve on the theoretical lessons 
and on the laboratory researches every year the students carry on technical and practical experiments within a forest located some 20 miles from Quebec, the property of the Laval University, or inside a township forest reserve well cared for, situated on the southern shore of the St.Lawrence.

The month of May is devoted to this practical training to which may be added the experience which the students get in the Berthiervilie Nursery. Is it necessary to say that this university training is completed during the sumner by the practice which the students achieve, in various sections of the province, under the direction of forest engineers or surveyors, working either for the government or for private enterprises?

So far, the School has granted the degree of Forest Engineer to 80 men who, for the most part, have found employment in work of an inventory nature, management and protection of the nationel domein from fire, and in the supervision of the cuttings carried on therein.

This isig in brief, the history of the school called the "Ecole d'Arpentage et de Genie Forestier". It is a very short history, such probably as is claimed to be the history of happy nations. Although brief, this history shows how deeply public opinion has been modified in regard to the problem of forest conservation and management. It recalls the important place which this question has assumed in the mind of those who are entrusted with the preservation of the stores of raw material and energy indispensable to the common welfare.

The Quebec Forestry School has succeeded, concurrently with the schools of Ontario, New Brunswick, and British Columbia in enhancing the value of the services which the forest engineer is able to render to the country and in raising this profession to the level which formerly was accupied solely by the lawyer's, the doctor's, or the civil engineer's professions. 